\title{
The Influences of Organization Development, Leadership, Motivation and Communication Toward Work Motivation and Its Implications Toward Teachers' Commitment at Islamic Boarding School In Cilacap Regency
}

\author{
Fathul Aminudin Aziz ${ }^{1} \&$ Sunhaji ${ }^{2}$ \\ ${ }^{1}$ Faculty of Economics and Islamic Business, State Institute on Islamic Studies Purwokerto, Indonesia \\ ${ }^{2}$ Faculty of Education and Teacher Training, State Institute on Islamic Studies Purwokerto, Indonesia \\ Correspondence: Sunhaji, State Institute on Islamic Studies Purwokerto. E-mail: a.sunhaji@gmail.com
}

Received: June 10, 2018

Accepted: July 11, $2018 \quad$ Online Published: August 31, 2018

doi:10.5539/ass.v14n9p50

URL: https://doi.org/10.5539/ass.v14n9p50

\begin{abstract}
Islamic boarding school institution is one of the oldest institutions in Indonesia, but its development is slower when it's compared to other institutions. Researcher realizes that it is important to analyze the influence of organizational development, leadership and communication toward employee motivation, and its implication toward the teachers' commitment at Islamic boarding school in Cilacap. To test the model and hypotheses, researcher uses the analysis of Structural Equation Model (SEM). Furthermore, to estimate the model, the author uses the program Analysis of Moment Structures (AMOS). Based on the research from Islamic boarding school teachers in Cilacap regency, it could be concluded that (1) organizational development, leadership, and communication give positive and significant impact on work motivation, either partially or simultaneously, (2) organizational development, leadership, communication, and work motivation give positive and significant impact on the commitment of Islamic boarding school teachers, either partially or simultaneously. Results of this study recommends that the commitment of Islamic boarding school teachers can be improved by motivating teachers in internal dimensions, especially those associated with the indicator in the form of an appreciation of their competences or scholarships.
\end{abstract}

Keywords: organizational development, leadership, communication, work motivation, and commitment

\section{Introduction}

Change is a must. It also occurs in the world of education. Islamic boarding school as an institution that is identical to the meaning of Indonesia's originality (indigenous), religious and legalistic is formally recognized as part of the national education system, which directly engages in developing themselves. Many Islamic boarding schools are no longer oriented to curriculum based on religion (Religion-based curriculum), but also talks about the question of curriculum nowadays society (society-based curriculum).

Islamic boarding school education is mainly important to the development of Human Resources in order to have a better life and a good attitude to humanize human being (humanist). But on the other side, Islamic boarding school teachers have their own problems and they must be continually motivated to be more professional. Along with the models, adopting modern education should be done immediately in order to become "Centre of Muslim Revitalizations" in Indonesia.

Many approaches must be addressed for the boarding school from managerial, organization, human resources, communication, science and religious knowledge. Empirical rational approach should be done, in an effort to get closer to the traditional Islamic boarding school community, together with rational and empirical approach to be something that should be done immediately. In the end, these efforts will finally enhance the appreciation of the Islamic boarding school community members, especially to the teachers at the Islamic boarding school on scholarship with the more complex domain. It means that it's not only the dogmatic theology, but a religion that supported the narrative which is born of the rational and empirical approach it's results from the study of science and skills.

The effort to near upon Islamic boarding school communities to the tradition of rational and empirical 
approaches can be done by performing the human resources diversification, managerial, scientific, and educational research territory on the education institution in Islamic boarding school. More explicitly, the existence of education institution which reviews general disciplines (non-religious) as domain final study in Islamic boarding school could be a real strategic option in order to increase the motivation of the teachers that finally will be able to increase the commitment of Islamic boarding school teachers who is still considered having lack motivation.

\section{Summary Problems}

Based on the above description, it can be summarized as follows:

1. Is there any influence of organizational development to the teachers' motivation of Islamic boarding school?

2. Is there any leadership influence to the teachers' motivation of Islamic boarding school?

3. Is there any influence of communication to the teachers' motivation of Islamic boarding school?

4. Is there any influence of organizational development, leadership and simultaneous communication to the teachers' work motivation of Islamic boarding school?

5. Is there any influence of organizational development to the teachers' commitment of Islamic boarding school?

6. Is there any leadership influence to the teachers' commitment of Islamic boarding school?

7. Is there any influence of the communication to the teachers' commitment of Islamic boarding school?

8. Is there any influence of work motivation to the teachers' commitment of Islamic boarding school?

9. Is there any influence of organizational development, leadership, communication and work motivation simultaneously to the teachers' commitment of Islamic boarding school?

\section{Research Purposes}

Based on the problems formulation, the purposes of this study, as follow:

1. To analyze and examine the influence of organizational development to the teachers' motivation of Islamic boarding school in Cilacap Regency, Central Java Province.

2. To analyze and determine the effect of leadership to the teachers' motivation of Islamic boarding school in Cilacap Regency, Central Java Province.

3. To analyze and determine the effect of communication to the teachers' motivation of Islamic boarding school in Cilacap Regency, Central Java Province.

4. To analyze and examine the influence of organizational development, leadership and simultaneous communication to the teachers' motivation in Cilacap Islamic boarding school, Central Java Province.

5. To analyze and examine the influence of organizational development to the teachers' commitment of Islamic boarding school in Cilacap Regency, Central Java Province.

6. To analyze and determine the effect of leadership to the teachers' commitment in Cilacap Islamic boarding school, Central Java Province.

7. To analyze and determine the effect of communication to the teachers' commitment of Islamic boarding school in Cilacap Regency, Central Java Province.

8. To analyze and determine the effect of motivation to the teachers' commitment of Islamic boarding school in Cilacap Regency, Central Java Province.

9. To analyze and examine the influence of organizational development, leadership, communication and work motivation simultaneously to the teachers' commitment of Islamic boarding school in Cilacap Regency, Central Java Province.

\section{Theoretical Basis}

Organization Development (OD) is a scientific instrument to enhance organizational effectiveness and health because it contains a number of elements of $\mathrm{OD}$, which is planned, covering the entire organization, long-term impact, involving top management and the use of various forms of intervention based on behavioral approaches (Siagian, 2004, pp. 3-14).

According to Spillane (2006, p. 10), the leader is a change agent with activity to affect people over the influence these people to him. Similarly, Stuart and Morgan (2002, p. 352), says that the leaders are expected to have an ability to influence, giving instructions and also be able to determine the individual to achieve organizational 
goals.

Daft (2008, p. 363) gives interpretation to the motivation as internal forces or an external person that rises enthusiasm and resistance to do a series of specific actions.

Hamalik (2007, p. 158) says that the motivation is the change of inner person's energy which is characterized by the emergence of feelings and reactions to achieve the goal. While Barelson and Steiner (2001:115) points out that the motivation is an inside person condition which encourages, evokes, or mobilizes and directs or distributes behavior to gain the goal. This includes the entire category, motivational impulses, desires, needs and similar power (Siagian, 2003, p. 95).

Mathis and Jackson, Angelo (2001, p. 99) argues that organizational commitment is the level of trust and acceptance human resources or employees to organizational goals and have a desire to stay in that organization. Kreitner and Kinicki, Angelo (2003, p. 274) points out that organizational commitment reflects on how an individual identifies himself with the organization and committed to goals stated before.

Dimensions of organizational commitment by Meyer and Allen, as written by Luthans, Sweeney and McFarlin (2002, p. 237) has three main components, namely:

affective commitment, including the emotional connection with the organization and the involvement of employees in the organization; continuance commitment, including the things that underlie employee loyalty to the organization; normative commitment, the employees feeling of obligation that he has to give to the organization.

While Jaros in Laka-Mathebula (2004, p. 15) distinguishes organizational commitment in three dimensions, namely: (1) affective, it's the level of psychological attachment of individuals to be employees within the organization, (2) continuance, it's the feeling of individuals because of the high risk that will be taken when leaving the organization, (3) moral, it's the level where individuals are psychologically tied to the goal of being an employee in an organization through internalization of the goals, values, and mission.

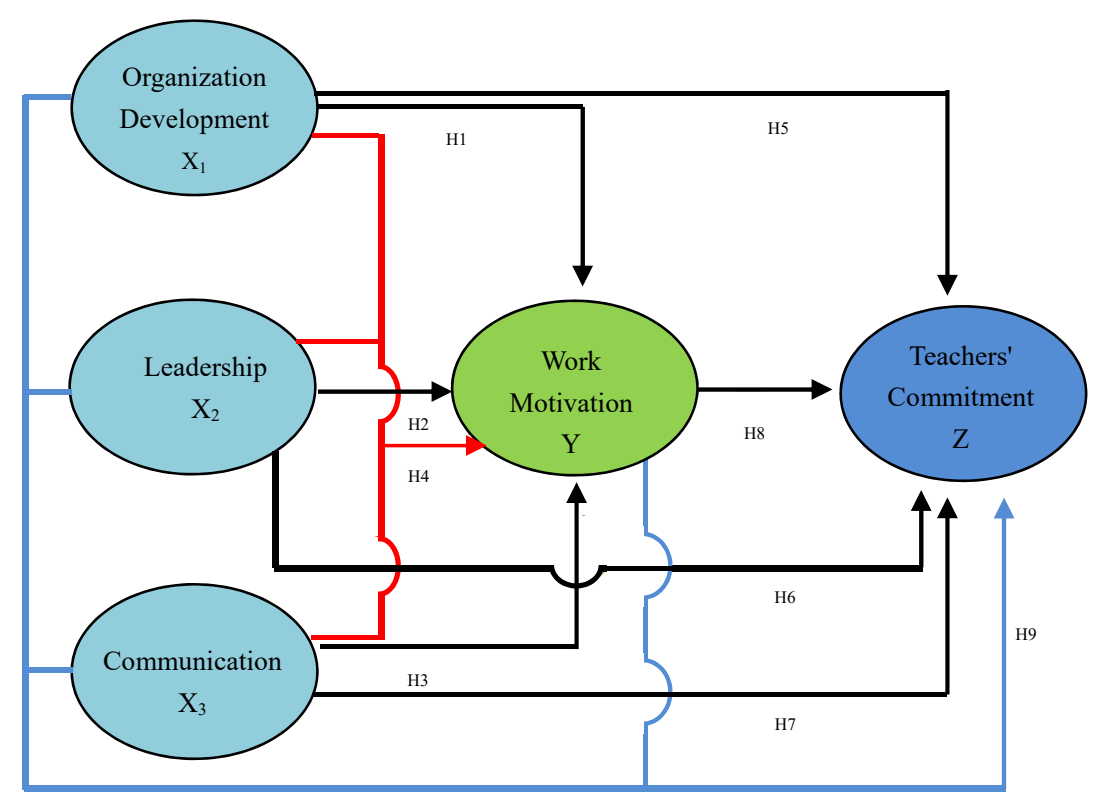

Figure 1. Framework Research Model

\section{Research Methods}

This study was implemented from January 2011 to July 2011 and located throughout the Islamic boarding schools which have formal institutions in Cilacap regency, Central Java. The research method is adopted for the two interests, they are descriptive and inference. First, the descriptive research is aimed to obtain a description of the characteristics of influence. In Arikunto Suharsimi (2010, p. 54), descriptive study is conducted by researchers in the hope that the result of the study is in the form of description, depiction or description of something. Second, the inference will test the truth of a hypothesis through data collection.

Models and hypotheses are tested by using analysis of Structural Equation Modeling (SEM). According Waluyo, Minto (2009, pp. 15-25), a complete SEM model basically consists of a Measurement Model and Structural 
Model. Measurement Model is aimed to confirm a dimension or factor based on empirical indicators. While Structural Model is a model through structural relationships among factors that make causality.

\section{Discussion}

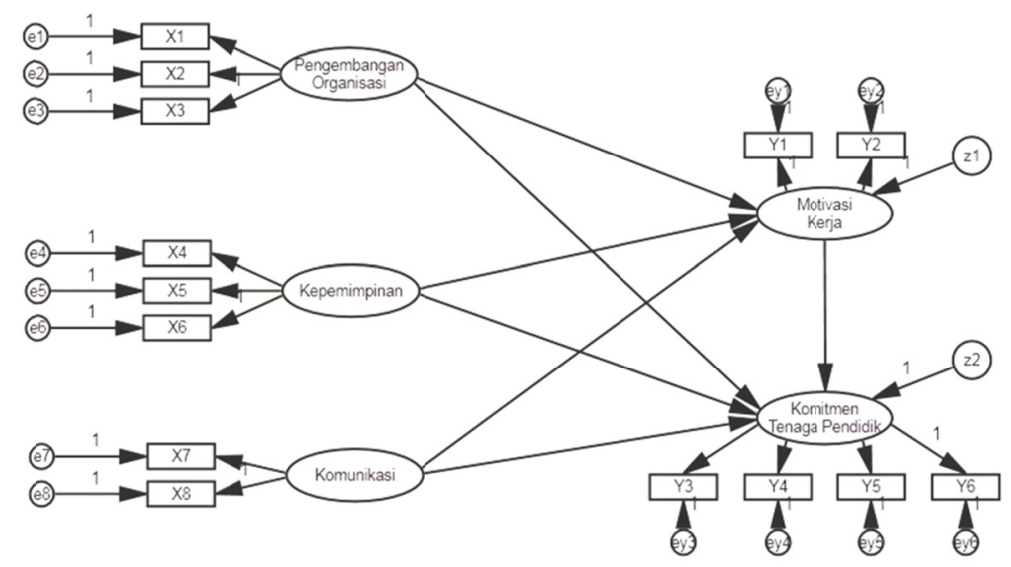

Figure 2. Full Structural Equation Model

The result of this research concords with Tiyagi's opinion in Wibowo (2006), he says that organizational development is a planned effort related to the increasing of creativity, skill problem solving, instructional, and human progress in organization, and it is proven that organizational development gives significant influence to work motivation. The value of Critical Ratio (CR) on the influence of organizational development to the work motivation amounts to 2,610. This indicates that $C R$ value $>t_{\text {table }}(2,610>1,960)$. Thus the hypothesis which indicates organizational development gives significant influence with work motivation is received.

To testify the influence of organizational development toward work motivation, it indicates that the value of highest dimension is human resource, and it amounts to 0,748. Thus the human resources dimension must be maintained, especially indicators that have the highest value, that is purpose determination. While managerial and organizational dimensions should continuously be improved in order that the teachers' work motivation of Islamic boarding schools always increase (Sunhaji, 2017).

Leadership, in a broad sense, is an activity to influence the behavior of others, or the art of influencing human behavior, both individuals and groups. Leadership should not be limited by the rules, the leadership also does not have to be bound to occur in a certain organization, but leadership can occur anywhere, as long as someone shows his ability to motivate teachers.

Leadership gives significant influence on work motivation. Value of Critical Ratio (CR) on leadership influences on work motivation is at 2.496. This indicates the value of $\mathrm{CR}>$ from $\mathrm{t}_{\text {tabel }}(2.496>1.960)$. Thus, the hypothesis which indicates leadership significantly influence work motivation is received.

The argumentation of leadership influence to work motivation suggests that the value of the highest dimension is value system which has score 0,833 . Thus, the value system dimension must be maintained, especially indicators that have the highest value, that is, appreciation to the performance of subordinates, while the dimension of behavior and competence should be improved in order to increase teachers' motivation.

Communication gives significant influence on work motivation. Value of Critical Ratio (CR) on communication influences to the work motivation is at 2.069. This indicates the value of $\mathrm{CR}>$ from $\mathrm{t}_{\text {tabel }}(2.069>1.960)$. Thus the hypothesis which indicates communication significantly influence work motivation is received.

The argumentation of communication influence on work motivation shows that the value of the highest dimension is the horizontal dimension which has score 0.773 . Thus, the horizontal dimension must be maintained, especially indicators that have the highest value, that is, the available time to communicate. While the vertical dimension must be increased in order that the work motivation of teachers in Islamic boarding schools always develops.

This is relevant to Robin's opinion (2002) that communication maintai simultaneously ns motivation with explanation to the employees on what to do, how well they do and what can be done to increase the commitment if it is at below standard. Theory of motivation is a concept that gives an explanation of the person's needs and 
desires and it also directs their actions.

Motivation is an activity to give encouragement to someone or yourself to take a desired action. In addition, it also drives people to carry out their activities. If people are motivated to carry out their activities, they demonstrate their work enthusiastically. This action is caused that they have sense of belonging, and it is a positive choice for them to do it. When motivation has been owned by each of teachers then is expected to develop his responsibility towards his job. It can also build willingness to participate in achieving organization goals, and finally, it will create a conducive working environment and increase the commitment of teacher in his instructional.

Organizational development, leadership, and communication give simultaneously significant influence toward work motivation. Based on the above results, it can be seen that the organizational development, leadership, and communication influence toward work motivation and it indicates value $\mathrm{R}$ square of 0,803 . This suggests that organizational development, leadership, and simultaneous communication have a significant contribution to the work motivation.

The argumentation of organizational development, leadership, communication partially or simultaneously influence the work motivation. It can be seen that the most dominant variable is organizational development with the highest value dimension on human resources which has score 0.748 . Thus the human resources dimension must be maintained, especially indicators that have the highest value, that is, orientation. While the other dimensions of each variable must be improved either partially or simultaneously in order that the work motivation of teachers in Islamic boarding schools increases.

Organizational development gives significant influences on the teachers' commitment. Value of Critical Ratio (CR) on the influence of organizational development to the teachers' commitment amountes to 2,016. This indicates that the value of $\mathrm{CR}>$ from $\mathrm{t}_{\text {tabel }}(2.016>1.960)$. Thus the hypothesis which indicates organizational development gives significant influence to the teachers' commitment is received.

The argumentation that organizational development influences significally to the teachers' commitment is shown that the value of the highest dimension is the human resources, it has score 0.748 . Thus the human resources dimension must be maintained, especially indicators that have the highest value, that is orientation, while managerial and organizational dimensions should be increased so that the commitment of Islamic boarding school teachers can improve.

Leadership gives significant influence upon the teachers' commitment. CR values of leadership influence toward the teachers' commitments amounts 2,072. This indicates the value of $\mathrm{CR}>$ from $\mathrm{t}_{\text {tabel }}(2.072>1.960)$. Thus, the hypothesis which indicates leadership influences the teachers' commitment is proved.

Discussion of leadership influence the teachers' commitment points out that the value of the highest dimension is the value system which has score 0.833 . Thus, the value of the system dimensions must be maintained, especially indicators that have the highest value, that is, appreciation to the performance of subordinates. While the dimension of behavior and competence should be continiously improved so that teachers' commitment gets higher.

Communication between leaders and subordinates cannot be separated from the paternalistic culture, that is, leaders rarely or never give authority to their subordinates to act independently, take initiative, and make decisions. This is because the communication made by leaders to subordinates is formal. Because there is a distance of organizational structure between leaders and subordinates. The consequences of this behavior is that the subordinates are not used as a source of information, ideas, and suggestions. In the absence of information, ideas, and suggestions from subordinates, a leader will not know the weaknesses and lack so that the leader will be bankrupt. On the other hand, the presence of information, ideas, and suggestions from the subordinates, the leader can state a future plan to increase his commitment and his subordinates as well.

With a good leadership, teachers feel trust, admiration, loyalty and respect for leaders and teachers are motivated to do more than expected. Leaders must be able to make teachers more aware of the importance and value of the work and persuade them not to prioritize their self-interest but for the sake of a larger organization.

Good leadership can develop the skills and confidence to the teachers about responsibility more and more in an organization that gives an authority. With this kind of leadership, it will be able to increase the commitments that had been made. In turn, the teachers will prioritize to the shared or common interest than personal one.

Communication gives significant influence to the teachers' commitment. Value of Critical Ratio (CR) on communication influences toward the teachers' commitment is equal to 2.038 . This indicates that the value is $\mathrm{CR}>$ from $\mathrm{t}_{\text {tabel }}(2.038>1.960)$. Thus, the hypothesis which indicates the communication influences the teachers' 
commitment is proved.

Communication influences to the teachers' commitment indicates that the value of the highest dimension is the horizontal dimension which has score 0.773 . Thus the horizontal dimension must be maintained, especially indicators that have the highest value, that is available time to communicate, while the vertical dimension must be increased in order that the work motivation of teachers in Islamic boarding school continuously to increases.

Work motivation gives significant influence to the teachers' commitment. Value of Critical Ratio (CR) on the influence of motivation to the teachers' commitment is at 2,097. This indicates the value of CR $>$ from $t_{\text {tabel }}$ $(2.097>1.960)$. Thus, the hypothesis which indicates motivation influence significantly to the teachers' commitment received.

Work motivation influences toward the teachers' commitment. It indicates that the highest value is the internal dimensions and has score 0.799 . Thus the internal dimensions must be maintained, especially indicators that have the highest value, that is scholarship and skill appreciation, while the external dimensions and indicators should be improved so that so that teachers' commitment get higher.

Organizational development, leadership, communication and work motivation give simultaneously significant influence to the teachers' commitment.

Based on the above results, it appears that organizational development, leadership, communication, and motivation influence the teachers' commitment which is indicated the value of R square of 0.903 . This suggests that organizational development, leadership, communication, and work motivation have simultaneously a significant contribution to the teachers' commitment.

Organizational development, leadership, communication and work motivation influence jointly to the teachers' commitment and shows that the most dominant variable is work motivation on the internal dimensions, that is 0.799. Thus the internal dimensions must be maintained, especially indicators that have the highest value, that is scholarship / skill appreciation, while the dimensions and other indicators should continue developing so that the teachers' commitment in Islamic boarding school in Cilacap District continues can increase.

The teachers' commitment of Islamic boarding school is built together with the organizational development, the pattern of democratic leadership, good communication, and maintained motivation. Organizational commitment is a psychological construct that is characteristic of relationship organization members with their organization. Teachers who are committed to the organization will be able to survive as part of an Islamic boarding school than members who do not have a commitment to the Islamic boarding school.

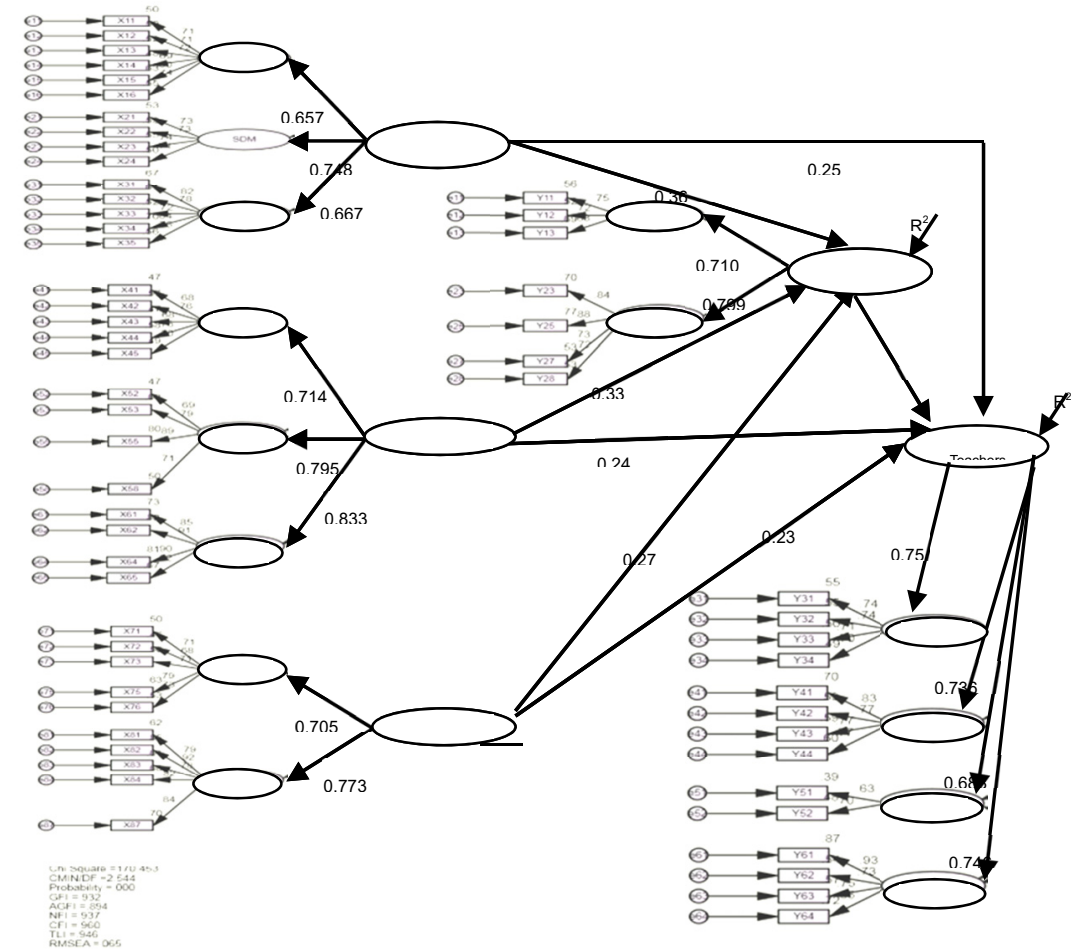

Figure 3. Full Structural Model 


\section{Conclusion}

On the above analysis, it can be concluded that organizational development, leadership, and communication affect the teachers' motivation of Islamic boarding school, it is proved by the value of $\mathrm{R}$ square of 0,803 . This shows that organizational development, leadership, and communication have simultaneously a significant contribution to the work motivation. Thus the work motivation of teachers in Islamic boarding school can be improved by developing the organization, effective leadership, and improve the quality of communication.

Evidence of organizational development, leadership, communication partially or simultaneously influence the work motivation suggests that the most dominant dimension is the dimension of organizational development with the highest dimension value on human dimensions, that is 0.748 . Thus the human dimension must be maintained, especially indicators that have the highest value, namely determination indicator. While other dimensions of each variable must be improved either partially or simultaneously in order that work motivation of teachers in Islamic boarding school can increase.

Organizational development, leadership, communication, and motivation affect teachers; it's proven by commitment to the value of $\mathrm{R}$ square of 0.903 . This suggests that organizational development, leadership, communication, and work motivation have simultaneously a significant contribution to the commitment of teachers. Based on these inventions, a commitment means teachers can be improved by developing organizational Islamic boarding school, leadership, communication, and work motivation either partially or simultaneously, with the most dominant variable is work motivation which has highest score in internal dimension of 0,799 . Thus, the internal dimension must be maintained, especially indicator which has the highest value, that is the indicator of scholarship/diploma appreciation.

\section{Recommendations}

The results of this study recommends that the commitment of Islamic boarding school teachers can be improved by motivating teachers in internal dimensions, especially those related to the indicators in the form of an appreciation of scholarship or skill.

In addition, the organizational development of Islamic boarding school in the development of Human Resources (HR) is also a recommendation of this study to continue intensively to be implemented in order to increase the motivation of Islamic boarding school teachers.

As we know that the main source of inspiration in forming ideology in Islamic boarding school community is the norm or the doctrine of Islam. Therefore, the cognitive orientation of Islamic boarding school community is, of course, aligned with the ideal life which is harmoneous to the norm or the doctrine of Islam.

On the other hand, the dynamics of today's social norms or ideals demanding doctrine of Islam which is indicated by a variety of empirical evidence as desired so that its significance can be undergone not only in real life today, but also in the hereafter.

Thus, besides dogmatic approach, the need of rational and empirical approach in narrating various ideal norms or the doctrine of Islam become an absolute precondition for religious life in today's contemporary era.

In the education world of Islamic boarding school, rational and empirical approach are still a very rare item. Such an approach is more prevalent in the world of general disciplines (non-religious). In consideration of the urgent need for the use of rational and empirical approach, the Islamic boarding school community efforts to get closer to the tradition of rational and empirical approach are also something that should be done immediately. This effort will enhance the appreciation of Islamic boarding school community member, especially teachers in the Islamic boarding school on the scholarship with a more complex domain, meaning that not only dogmatic theology, but religion which is supported by a narrative born from rational and empirical approaches as the result of the study of general disciplines (non-religious), finally increasing recognition of the ability or skill will be able to increase the motivation of teachers.

Institutionally, the effort to bring Islamic boarding school community to the tradition of rational and empirical approach can be done by diversifying the areas of education studies at the institution in Islamic boarding school. More explicitly, the existence of institutions that assess general disciplines (non-religious) as a complement domain studies in an Islamic boarding school can be a real choice effort that is very strategic.

In turn, the alumnus of educational institution who studied the general disciplines (non-religious) will strengthen the narrative of Islamic norms, and ultimately will strengthen belief about the importance of achieving an organizational goals determined together.

Strong beliefs about the importance of achieving an organizational goals determined together will further 
strengthen the position of the organizational direction as something that drives the activities of the entire organization members. A strong belief about the importance of achieving determined organization goals strategically will increase the commitment of all teacherrs in Islamic boarding school.

Academic advice for the next researchers is to develop further research to expand the study of organizational development, leadership, communication, motivation, and commitment of teachers or other variables with different research objects.

\section{References}

Arikunto, S. (2010). Prosedur Penelitian Suatu Pendekatan Praktek. Jakarta: PT Rhineka Cipta.

Caroselli, M. (2000). Leadership Skill for Managers. New York: McGraw-Hill.

Daft, R. L. (2008). Management-Manajemen. Alih bahasa oleh: Diana Angelica. Jakarta: Salemba Empat.

Hamalik, O. (2007). Proses Belajar Mengajar. Jakarta: PT Bumi Aksara.

Handoko, T. H. (2003). Manajemen, jilid 2. Yogyakarta: BPFE.

Kreitner dan Kinicki, A. (2003). Organizational Behavior. New York : McGraw-Hill Companies, Inc.

Laka-Mathebula, M. R. (2004). Modelling the Relationship Between Organizational Commitment, Leadership Style, Human Resource management Practices and Organizational Trust. Faculty of Economic and Management Science: University of Pretoria. p. 15

Luthans, F., \& Sweeney, dan McF. (2002). Organizational behavior: Solutions for Management. New York: McGraw-Hill Company.

Mathis dan Jackson, A. (2001). Perilaku Organisasi, Buku 1, Edisi Kelima, alih bahasa oleh Djarkasih, Jakarta: Salemba Empat.

Siagian, S. P. (2004). Pengembangan Sumber Daya Insani. Jakarta: Gunung Agung.

Spillane, J. P. (2006). Distributed leadership. San Francisco: Jossey Bass.

Stuart, R. D., \& Morgan, B. B. (2002). Library and information centre management. USA: Library Unlimited.

Sunhaji. (2017). Between Social Humanism and Social Mobilization: The Dual Role of Madrasah in The Landscape of Indonesian Islamic Education. Journal of Indonesian Islam, 11, 125-144. https://doi.org/10.15642/JIIS.2017.11.1.125-144

Waluyo, M. (2009). Panduan dan Aplikasi Struktural Equation Modelling (untuk Aplikasi Model dalam Penelitian Teknik Industri, Psikologi, Sosial dan Manajemen). Jakarta: PT Indeks. Retrieved from http://ejournal.upnjatim.ac.id/index.php/tekmapro/article/download/305/250

\section{Copyrights}

Copyright for this article is retained by the author(s), with first publication rights granted to the journal.

This is an open-access article distributed under the terms and conditions of the Creative Commons Attribution license (http://creativecommons.org/licenses/by/4.0/). 